\title{
Impact of Gender and Faculty on Study Habits and Attitudes of College Students
}

\author{
Dr. Indrajitsinh. D. Thakor ${ }^{1}$
}

\begin{abstract}
:
The purpose of this study was to determine the attitudes of college students toward his study habits and attitudes. In this investigation also sought to ascertain of gender (Male and Female) and faculty (Arts and Commerce) influence towards study habits and attitudes. In this research paper study habits and attitudes inventory was used. The random sample $(\mathrm{N}=850)$ was taken from different colleges. (Male - 425 and Female - 425) out of 425 male, 213 were from arts and 212 were commerce faculty. Similarly, female group consisted of 425 female, 210 were from arts and 215 were commerce faculty. In this study the results indicated that there was no significant difference in study habits and attitudes of male and female. Similarly, on significant difference was found between arts and commerce faculty in study habits and attitudes. Detail are given in paper itself.
\end{abstract}

Keywords: Typical Personality Profile Of School Students, Gender Difference

Learning is a highly complex problem in psychology. We know the different psychologists have tried to explain it in their own ways. Many factors greatly influence the process of learning aptitudes viz, heredity, effects of environment, his maturity, his interest in the subject and capacity of understand, member of his family, friends, qualities of teacher, methods of learning etc.

Mostly every student select a particular method of study on the basis of his Study Habits and Attitudes. Study Habits undoubtedly make invaluable contribution to students future academic achievements and professional successes. Hence, it is necessary to acquire the knowledge of Study Habits and Attitudes of students by scientific methods.

\section{OBJECTIVES OF STUDY:}

(i) To Study the impact of Gender on Study Habits and Attitudes Inventory.

(ii) To Study the impact of Faculty on study Habits and Attitudes Inventory.

\footnotetext{
${ }^{1} \mathrm{M} \& \mathrm{~V}$ ARTS AND COMMERCE COLLEGE, HALOL
} 


\section{METHODOLOGY:}

\section{Sample:}

The sample of the present study consisted of 850 respondents was randomly selected from different colleges. (Male - 425 and Female - 425) out of 425 male, 213 were from Arts and 212 were Commerce faculty. Similarly female group consisted of 425 female, 210 were from Arts and 215 were Commerce faculty.

\section{Tool:}

Study Habits and Attitudes Inventory, Constructed and Standardized by Dr .I.D.Thakor (2014) was used. The scale consists of 29 items. This inventory consisted of 29 items which includes 16 positive and 13 negative statements.

\section{Hypotheses:}

(i) There will be no significant difference between the mean scores of Study Habits and Attitudes Inventory of male and female college students.

(ii) There will be no significant difference between the mean scores of Study Habits and Attitudes Inventory of Arts and Commerce College students.

\section{Procedure:}

The data collected in small groups in the classroom situation. During the testing session respondents were instructed in brief about the purpose of investigation. They were instructed to read the items carefully and to put a tick mark in one of the provided spaces according to their opinion "YES" or "NO". They were assured about confidentiality of their responses. All the forms put on transparency (Scoring Key) one by one and calculate row scores of all forms and then calculate MEAN, SD and " $t$ " Value of data.

\section{RESULTS AND DISCUSSION:}

The finding of the study on problem of relationship between Gender and Faculty of Study Habits and Attitudes of College students, Result are given bellow.

TABLE:I Sample of the study

\begin{tabular}{|c|c|c|c|c|}
\hline \multirow{2}{*}{ Sr. No } & \multirow{2}{*}{ Gender } & Arts & Commerce & \multirow{2}{*}{ Total } \\
\cline { 3 - 5 } & & 213 & 212 & 425 \\
\hline 01 & Male & 210 & 215 & 425 \\
\hline 02 & Female & 423 & 427 & \\
\hline 03 & Total & \multicolumn{3}{|c|}{ Grand Total: $\mathbf{8 5 0}$} \\
\hline 04 & \multicolumn{3}{|c|}{} \\
\hline
\end{tabular}


Table No: I, Shows that the total data of 850 respondents were collected for the study of impact of Gender and Faculty on Study Habits and Attitudes.

TABLE:II MEAN, SD and “ $t$ " Value of of Study Habits and Attitudes Inventory for Gender (Male and Female).

\begin{tabular}{|c|c|c|c|c|c|c|c|}
\hline Sr. No & Gender & N & Mean & SD & df & $\begin{array}{c}\text { "t " } \\
\text { Value }\end{array}$ & Sig. Level \\
\hline 01 & Male & 425 & 17.84 & 4.56 & 848 & 0.09 & NS* \\
\hline 02 & Female & 425 & 18.72 & 4.02 & 848 & \\
\hline
\end{tabular}

$* \mathrm{NS}=$ Not Significant. $\quad$ Table Value. $=1.96$

Level of Significant $=0.05 \quad$ Calculated $t=0.65$

Table No: II Shows that the mean scores of Study Habits and Attitudes for Male and Female studying in college are 17.84 and 18.72 respectively. The " $t$ " Value difference between in 0.09. Which is not significant at 0.05 level. The table value is 1.96 at $848 \mathrm{df}$. There for the null hypothesis is accepted. There for, it can be said that there is no significant difference between the mean scores of Study Habits and Attitudes of Male and Female college students.

TABLE:III MEAN, SD and " $t$ " Value of of Study Habits and Attitudes Inventory for Faculty (Arts and Commerce).

\begin{tabular}{|c|c|c|c|c|c|c|c|}
\hline Sr. No & Faculty & N & Mean & SD & df & $\begin{array}{c}\text { “t } \mathbf{t}^{\text {" }} \\
\text { Value }\end{array}$ & Sig. Level \\
\hline 01 & Arts & 423 & 19.11 & 3.93 & 848 & 0.18 & NS* \\
\hline 02 & Commerce & 427 & 17.46 & 4.53 & 848 & \\
\hline
\end{tabular}

$* \mathrm{NS}=$ Not Significant. Table Value. $=1.96$

Level of Significant $=0.05 \quad$ Calculated $\mathrm{t}=0.18$

Table No: III Shows that the mean scores of Study Habits and Attitudes for Arts and Commerce studying in college are 19.11 and 17.46 respectively. The " $t$ " Value difference between in 0.18, Which is not significant at 0.05 level. The table value is 1.96 at $848 \mathrm{df}$. There for the null hypothesis is accepted. There for, it can be said that there is no significant difference between the mean scores of Study Habits and Attitudes of Arts and Commerce college students.

\section{CONCLUSION:}

(i) In the present study there is no significant difference between Male and Female student on Study Habits and Attitudes Inventory. It shows that Gender does not play any significant role so far as Study Habits and Attitudes is concerned.

(ii) In the present study there is no significant difference between Arts and Commerce student on Study Habits and Attitudes Inventory. It shows that Faculty does not play any significant role so far as Study Habits and Attitudes is concerned. 


\section{REFERENCE:}

Andersion, Robert, P.and Kuntz, \& James,. E. (1959). The Survey of Study Habits and Attitudes In a College Counseling Center. Personn. Gide., 37

Garrett, H. E. (1958). Statistics in Psychology and Education, (5 ${ }^{\text {th }}$ Ed.). Longmans, Green and Co., New York.

Jamuar, K, K. (1973). Study Habit of College Student, Indian International Publication, P.B.79, Allahabad, India 